Metallophysics and Advanced Technologies

Металофіз. новітні технол.

Metallofiz. Noveishie Tekhnol.

2020 , vol. 42 , No. 5 , pp. $731-751$

https://doi.org/10.15407/mfint.42.05.0731

Reprints available directly from the publisher
(C) 2020 G. V. Kurdyumov Institute for Metal Physics, National Academy of Sciences of Ukraine Published by license under

the G. V. Kurdyumov Institute for Metal PhysicsN.A.S. of Ukraine Publishers imprint.

PACSnumbers: 62.20.-x, 62.20.F-, 62.20.M-, 62.20.Qp, 81.40.Np, 81.40.Pq, 81.70.Bt

\title{
Analysis of Causes and Preventing Ways of Early Workability Loss of Three-Cone Rock Bit Cutters
}

\author{
R. S. Yakym and D. Yu. Petryna* \\ Drohobych Ivan Franko State Pedagogical University, \\ 24 Ivan Franko Str., \\ 82100 Drohobych, Ukraine \\ "Ivano-Frankivsk National Technical University of Oil and Gas, \\ 15 Karpatska Str., \\ 76019 Ivano-Frankivsk, Ukraine
}

We present the results of the study of a nature of damages of three-cone rock bits that have premature lost their workability. Physical-mechanical and metallographic indices of melting steel of cone bit with brittle fracture are established. The distribution of carbon concentration and hardness in hardened carburized layers of cone bit is studied. Metallographic analysis of the most common steels used in the worldwide practice of cone bits manufacturing is performed to find ways to prevent premature loss of cone bits' workability. The chemical composition and physical-mechanical and technological parameters are established, on the basis of which the conceptual requirements for the choice of steel and the quality of the technology of cone bits' strengthening are formulated for domestic production.

Key words: steel, brittle fracture, cone bit, crack resistance, durability, melting.

Представлено результати вивчення характеру пошкоджень шарошок гірничорудних тришарошкових бурових доліт, які передчасно втратили роботоздатність. Встановлено фізико-механічні та металографічні показники плавки сталі шарошки, що зазнала крихкого руйнування. Встановлено характер розподілу концентрації Вуглецю та твердості у загартованих цементованих шарах шарошки. Для пошуку шляхів запобігання передчасній втраті роботоздатності шарошок здійснено металографічний ана-

Corresponding author: Roman Stepanovych Yakym

E-mail: administrator@drohobych.net

Citation: R. S. Yakym and D. Yu. Petryna, Analysis of Causes and Preventing Ways of Early Workability Loss of Three-Cone Rock Bit Cutters, Metallofiz. Noveishie Tekhnol., 42, No. 5: 731-751 (2020), DOI: 10.15407/mfint.42.05.0731. 
ліз показників найпоширеніших сталей, які застосовують у світовій практиці виготовлення шарошок. Встановлено їх хімічний склад та фізико-механічні й технологічні показники, на основі чого сформульовано концептуальні вимоги щодо вибору сталі та якості технології зміцнення шарошок вітчизняного виробництва.

Ключові слова: сталь, крихке руйнування, шарошка, тріщиностійкість, довговічність, плавка сталі.

Представлены результаты изучения характера повреждений шарошек горнорудных трёхшарошкових буровых долот, преждевременно утративших работоспособность. Установлены физико-механические и металлографические показатели плавки стали шарошки, подвергшейся хрупкому разрушению. Установлен характер распределения концентрации углерода и твёрдости в закалённых цементируемых слоях шарошки. Для поиска путей предотвращения преждевременной потери работоспособности шарошек осуществлён металлографический анализ показателей распространённых сталей, применяемых в мировой практике изготовления шарошек. Установлены их химический состав и физико-механические и технологические показатели, на основе чего сформулированы концептуальные требования по выбору стали и качества технологии упрочнения шарошек отечественного производства.

Ключевые слова: сталь, хрупкое разрушение, шарошка, трещиностойкость, долговечность, плавка стали.

(Received February 14, 2020)

\section{INTRODUCTION}

Three-cone rock bit cutters are designed to destroy high-strength rocks. The rock-destroying part of cones is subjected by heavy loading. Difficult working conditions put forward a set of requirements for the use of materials, design features and technology of production and strengthening of cones. The nature of the wearing and their operating performance are changed vary widely. This requires regular analysis of the operating performance indicators, followed by a careful study of the nature of the destructions of the bits. Considerable experience has been gained in establishing a classification system according to the IADC [1] of drilling bit wearing. This classification makes it possible to analyse the main and typical causes of failure of drill bits. However, the analysis of the data of worked-out three-cone rock bit cutters revealed the facts of premature loss of their ability to work due to catastrophic wearing and fracture of the cones. In such cases, we have significant differences from the typical nature of the destructions of the drill bits. It sets the task of studying the peculiarities of the use of steels, their strengthening and the technology of production of threecone rock bit cutters. 


\section{ANALYSIS OF CONTEMPORARY FOREIGN AND DOMESTIC RESEARCH AND PUBLICATIONS}

In recent years, a lot of researches have been devoted to the study of the outlined problem [2-5], but not all aspects have been studied. In particular, along with the developed recommendations for the prevention of the cone bits brittle destruction, which includes requirements for the selection of melts and the application of strengthening parameters, there is no clear understanding of a comprehensive approach to ensure high operating performance of three-cone drill bits.

The design, technological and operational methods are used to increase drilling tool durability made of steel, aluminium and titanium alloys, hard alloys artificial diamonds.

Design methods, in particular, include a rational choice of materials and allowable load levels. Microelectrochemical methods [6, 7], macroelectrochemical methods for measuring the electrode potential [8-10], and methods for estimating voltage fluctuations on the corroding surface [11] are used during research in corrosive environments under different types of loads to specify materials for drilling tools. The resonance method [12] is used to determine the structural changes caused by plastic deformation. The following means are important: improving of transition groove configuration and conical thread profile of parts made of different materials [13, 14], usage of tread thickenings for aluminium drill pipes [15], the optimal choice of connection of drilling tool parts $[16,17]$. The rational choice of lubricants is used to provide a significant service life of drill bit supports [18]. In addition, composite tungsten-free materials may be promising for the manufacture of cutting elements of drill bits $[19,20]$.

The attention should be paid to the following technological methods: usage steel for drill bits to with minimal permissible deviations in chemical composition and physical and mechanical parameters, rational manufacturing of workpieces with simultaneous reinforcement of the steel matrix with tungsten carbide for the production of drill bits [21] and improvement of cutting technology [22].

Cutting and abrasive tools are used for machining of workpieces, which provides high quality of the surface layer of metal [23-25]. The technical means proposed in [26-28] are promising to be applied during machining of the gear cones of drill bits made of alloy steel. The systematic approach for assembling of products made of different materials [29] including for drill bits is a progressive direction too.

In addition, the technological methods also include drilling tool strengthening processes: surface alloying of steels [30-32], the formation of wear-resistant and functional coatings on their working surfaces [33-35]. Cones of drill bits are subjected to chemical and thermal treatment [3]. The works [36, 37] studied the influence of nickel on the 
course of diffusion processes in alloys was investigated, which is relevant for the selection of optimal modes of chemical-thermal treatment of nickel-doped steels, which are subjected to carburization during the manufacture of drill bit parts.

Operational methods include:

- selection of optimal drilling modes based on the force and thermal interaction of cutting elements with the rock [38-40], as well as taking into account the heterogeneity of rocks [41];

- selection of a rational layout of the drill string using aluminium and steel pipes for prevention fatigue failure [42] and the level of loads to prevent contact fatigue failure of parts of the working surfaces of drill bits [43];

- vibration protection of drilling tools through the use of vibration protection layouts, inertial vibration dampers $[44,45]$ and special drill shock absorbers and elastic spindles of downhole engines [46-48];

- providing thorough the well face cleaning from destroyed rock and wear products of drill bits [49], including inclined and horizontal wells [50]. To prevent fatigue failure of the drilling tool, the authors [51] developed an improved design of the fatigue damage indicator conical threaded connection of the drill string of pipes, and the state of the indicator predicts the residual life of the steel drilling tool. In [52-54], effective and at the same time safe ways to eliminate the capture of drilling tools made of steel, titanium and aluminium alloys in the well during emergencies, taking into account the stress state of the metal.

\section{PURPOSE AND TASKS OF INVESTIGATION}

The research aims to study destruction and presents the results of the study of the nature of damage to the cones, the analysis of chemical composition and physical-mechanical and technological characteristics. In order to find effective ways to prevent cases of sudden failures due to catastrophic destruction of cone bits, an analysis of the chemical composition and physical, mechanical and technological parameters of the most common steels used in world practice of cone bits production has been carried out. On the basis of the results of complex studies, recommendations are made to improve the operating parameters drill bits produced from domestic steel.

\section{EQUIPMENT AND INVESTIGATION}

Domestically and foreign manufactured drill steels were used study providing. IPSEN units were used to carry out the chemical heat treatment (CHT) in all cases. The units are equipped with a Carbo-oProf computer. All this allows us to model the processes of CHT and 
control the quality of processes. Carbon concentration was determined on the carbon analyser model AN-7529 according to the existing standard method. Microstructure was studied on specimens and grinders, on different parts of cone bits and was investigated according to the standard procedure. For this purpose, a universal microscope from MEIJI Techno (Japan) and a metallographic microscope from Charles Zeiss Jena (Germany) were used. In all cases, the hardness was measured according to the standard technique on the PMT-3 instrument. Energy-dispersive X-ray fluorescence analyser 'EXPERT 3L' was used to establish the expanded chemical composition of temples of cone bits and samples.

\section{MAIN RESEARCHES AND DISCUSSION}

Substantial reduction in operating performance, up to the stop of rock breakage, is often due to general abrasive wear of the cones, or partial or complete destruction of the cones body (Fig. 1). The presence of metal fragments from the chipped elements of the cone, carbide teeth and rolling elements on the bottom of the shaft increases the damage and destruction of the working surfaces. In particular, against the background of the general wear of the rock-breaking equipment, the destruction of the carbide insertion teeth, the damage to the working surface of the crowns and between the crowns due to slight distortions and plastic deformation were recorded. (Fig. 1, a). There have also been cases of general catastrophic abrasive wear, and the peaks at the cones No. 1 and No. 2 are chipped. Traces of considerable plastic deformation were detected on the working surface of the cone bits (Fig. $1, b)$. The sudden stop of the drill occurred because of the complete destruction of the tops of the cone bits and the general catastrophic abrasive wear of the bushings of the bushings, as well as of individual insertion carbide teeth (Fig. 1, c).

The emergency condition of the cone drills can be a consequence of the chipping of a large fragment with the loss of the rolling bodies from the cone No. 1, as well as the destruction in the dangerous section of the cone drill No. 2 between the crowns with the exposure of the lock ball bearing (Fig. 1, $d$ ). Under these conditions, abrasive wear of the work surfaces of the cones is maximal. If you do not stop drilling in time, the cone drills will suffer from even more destruction and more metal will fall out on the bottom. For example, the loss of the cone drill No. 1 is typical, and splits the vertex is chipped along the radius in the section of the carburized thrust end in the cone No. 2; in the cone No. 3 the top is chipped with the falling of the rolling bodies of the small rolling bearing (Fig. 1,e). Here, the general catastrophic abrasive wear is recorded on the working surfaces of the cones and the insertional rockbreaking equipment, and the individual insertion teeth are completely 
destroyed.

In some cases, the destruction of the cones occurs already in the first ten hours of operation of the bit. In particular, catastrophic consequences are resulted in the complete collapse of the shaft in a dangerous section between the crowns with the exposure of the lock ball bearing (Fig. 1, $d$ ). At the same time on the crowns of the cone there is a characteristic general abrasive wear from the presence on the face of
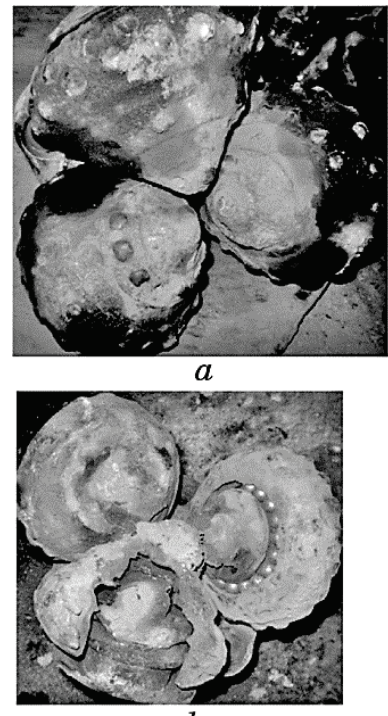

$d$
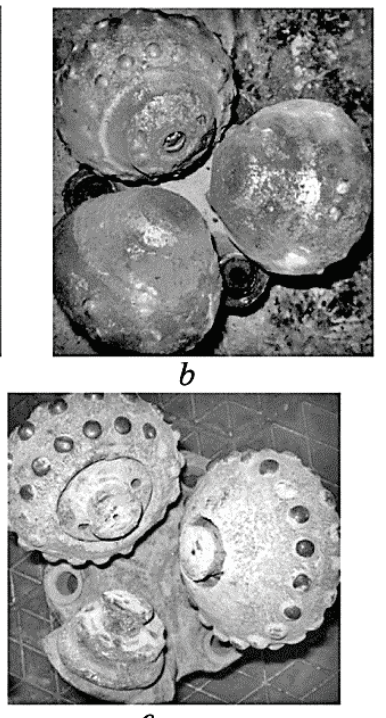

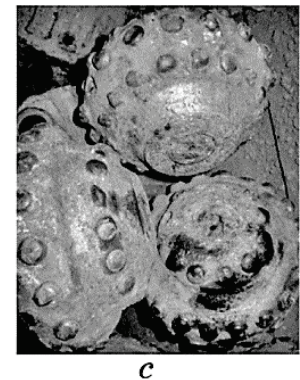

$c$

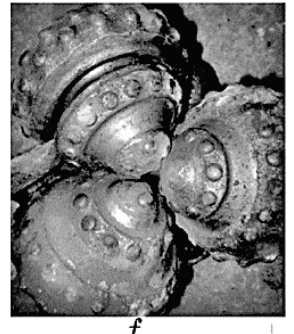

$f$

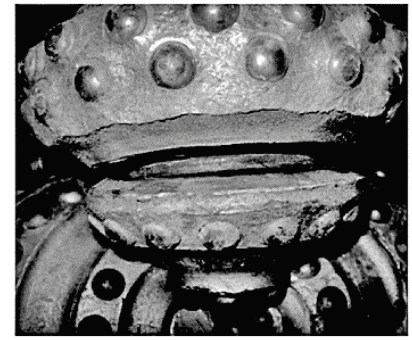

g

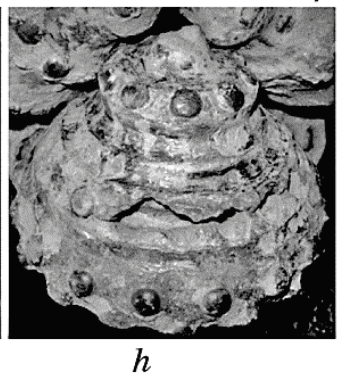

Fig. 1. General view of damage to the cones of worked out drilling bits during their operation for drill bits of different strength categories by M. M. Protodyakonov: $a$-drilling of rocks of 16-18 categories of strength, passage 96 points; $b$-drilling of rocks of 14-16 categories of strength, passage 128 points; $c$-drilling of rocks of 15 -18 categories of strength, passage 147.5 points; $d$-drilling of rocks of 18 category of strength, passage 72 points; $e$-drilling of rocks of 17 category of strength, passage 32.5 points; $f$-drilling of rocks of 18 category of strength, passage 11.5 points; $g-$ drilling of rocks of 18 category of strength, passage 18.5 points; $h-$ drilling of rocks of 16-19 categories of strength, passage 76 points. 
the metal. The fracture of the cone in the radial section between the crowns (Fig. 1, g) and the general plastic deformation of the crowns against the background of general slight wear were recorded. In other cases, anomalous cracking of cone drills and chipping of fragments of crowns from the system of cracks in the cross-section of the crown and carburized thrust end with the loss of the insertion of carbide teeth were observed (Fig. 1, $h$ ). The general abrasive wear and destruction of the work surface of the cone, especially between the crowns is also noted.

In general, the cones lose their workability because of the breakage of the tops, the destruction of the cones body, the wear of the working surfaces between the insertion rock destruction carbide teeth. The wear of the intercostal elements and the crowns causes the expose of shanks of the teeth and fall out. In some cases, sudden destruction of the cones in dangerous sections, indicating the fragile nature of the destruction was observed.

Metallographic studies were carried out to determine the causes of steel cone bits destruction. In particular, the macro-analysis revealed the fragile, rocky type of the fractured surface in the plane of destruction of the cone bits body and the crown elements (Fig. 2).

A considerable number of cracks of different lengths in the body of the cone were found, mainly oriented along the axis of symmetry of the cone (Fig. 2, $a$ ). The fracture planes are dominated by the fragile appearance of the rocky type of the fracture surface (Fig. 2, b, c). This suggests that the destruction occurred suddenly in the congested area of contact of the cone-downhole the plastic deformation, wearing of the working surfaces and destruction of rock destructed carbide teeth
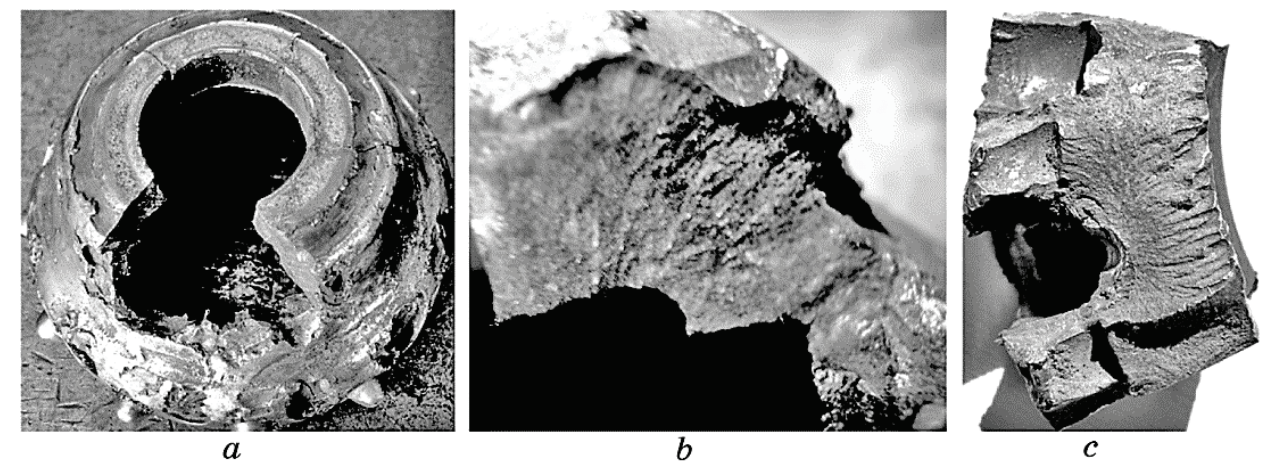

Fig. 2. Appearance of brittle fracture of cone bit elements: $a$ - the destroyed body of the cone with the loss of fragments including the top; $b$-macroscopic view of the fracture in the area of carburized thrust end face; $c$-macroscopic view of the fracture in the section from the crown of the cone to the large peripheral roller bearing. 


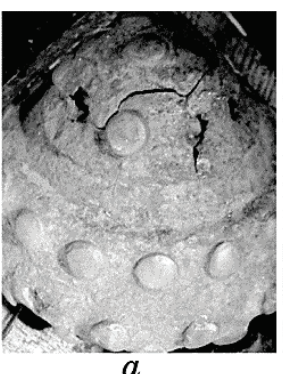

a

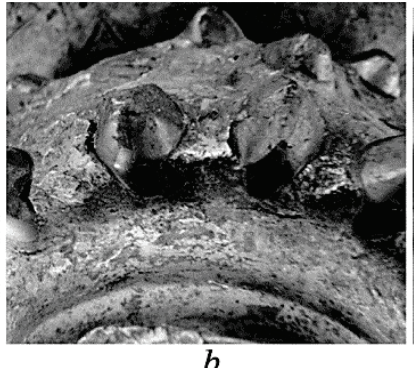

$b$

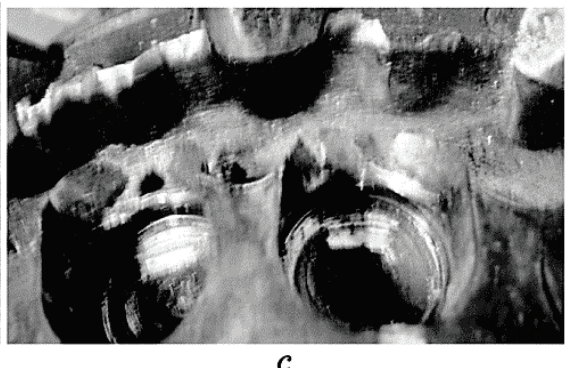

Fig. 3. The appearance of the destruction of the elements of the cone bit: $a-$ system oriented in different directions of cracks and destruction of the top of the cone; $b, c$-wear and plastic deformation of crowns, exposing shanks of carbide teeth.

occurred due to the presence of metal on the down hole.

A slightly different nature of the destruction of the vertices of the cones was also recorded (Fig. 3,a). Here, the cracks oriented in different directions originate in the hardened layers of the working surface of the cone and stop in the core. Insufficient strength of the cone bits causes intensive wear and plastic deformation between the crowns and the crowns themselves (Fig. 3, $b, c$ ). This significantly reduces the area of the dangerous section and accelerates the destruction of the cone bits into fragments.

The working surfaces of the thrust end of cone bits have typical fractures: general wear, material transfer, grasping and chipping of fragments of the carburized layer. Concentric cracks were fixed in cone bits that had brittle fracture, on the background of common typi-

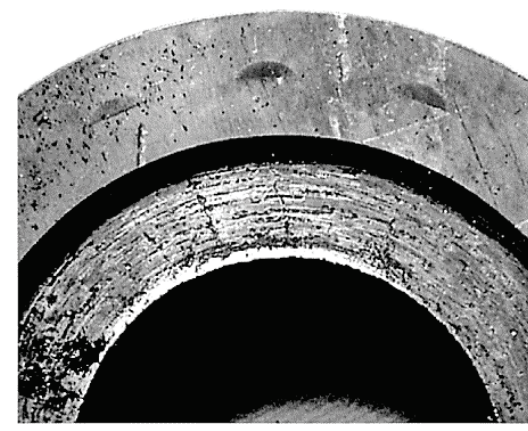

$a$

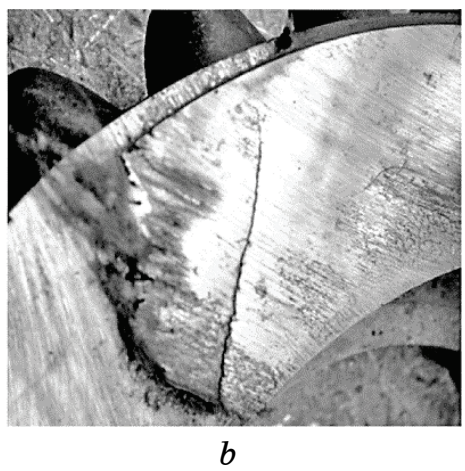

$b$

Fig. 4. Appearance of the template of cone bits with a radial cross section: $a-$ concentric cracks on the surface of the destroyed carburized thrust end face; $b$-randomly oriented cracks in the plane of cross-section of the thrust end of the circle around the crown with insertable carbide teeth. 
cal fractures of the carburized layer (Fig. 4,a). The cracks of different lengths and orientation were revealed by analysis of temples carved in the plane of cross section of the thrust end of the circle around the crown with insertion carbide teeth (Fig. $4, b$ ).

Based on years of experience in the production and operation of mining drill bits, as well as numerous data of systematic analysis of damage and loss of workability of bits, functionally oriented decomposition of the bundle was figured out (Fig. 5). This made it possible to formulate in a complex and at the same time more clearly the tasks for the effective solution of design and technological problems in the stages of producing of drill bits. Here the overriding task is to overcome the problem of choosing the best steel and to strengthen it for the manufacture of drills. At the same time it is necessary to solve simultaneously the following main tasks: ity;

- work surfaces should have high hardness to ensure high durabil-

- the cone bit body should provide high ductility rates to counteract dynamic and static loads;

- responsible elements must provide high elasticity and strength to

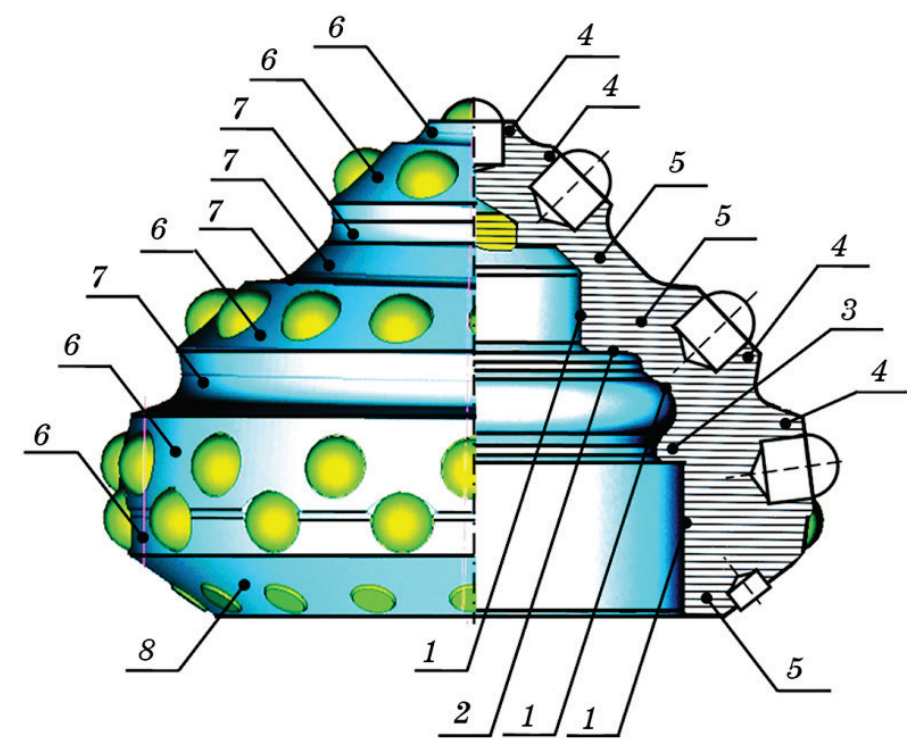

Fig. 5. Decomposition of a drill bit with formulation of requirements for functional elements: 1 -wear resistance under rolling friction; 2 -wear resistance under sliding friction; 3-strength against brittle or plastic fracture; 4crack resistance, ensuring the strength of the press joint 'cone bit shank of carbide tooth'; 5-strength and crack resistance to the action of static and dynamic loads; 6 -resistance to shock and abrasion wearing; 7 -wear resistance to hydro-abrasive wearing; 8-wear resistance to abrasive wearing. 
counteract plastic deformation;

- work surfaces should be highly resistant to the action of chemically active media.

At the same time, satisfying the formulated requirements is quite problematic because some of them exclude each other. Therefore, there are difficulties in formulating steel selection criteria, hardening technology parameters, etc. These issues have always caused problems [55, 56] and are still debatable in the drill bits manufacturing [2-5]. It is known [4] that steels are used for drill bits enterprises 'Hughes Christensen Co.', 'Smith International Inc.', 'Reed Tool Co.', 'Security DBS Dresser Industries Inc.', 'Varel Manufacturing Co.', etc. with strictly regulated parameters of chemical composition, purity and physicalmechanical and technological properties. At the same time, the experience of world practice in the manufacture of drill bits is embodied in ASTM, which is a guiding document for achieving a high level of quality of bits. However, reliable data on metallographic, physicalmechanical and technological indices of drill bit steels are not enough to improve the domestic technology of drilling bit production. Therefore, the metallographic analysis of the worked out drill bits, which lost their workability, was carried out first, and then the choruses of some well-known drilling bits manufacturers.

According to the standard technique templets were made from cone bit which has failure by fragile destruction. In Fig. 6 presents the results on the established distribution of the chemical composition of steel melting (Table 1) and technological and physical-mechanical parameters (Table 2). The greatest scattering of chemical elements is observed for $\mathrm{Cr}, \mathrm{Ni}$, Mo, which indicates a slight segregation of these elements (does not exceed the requirements of State Standard ГOCT 18895-97), which is typical for 14XH3MA-B steel melts made according to Technical Conditions TY14-550-51-2004.

Contamination of steel by non-metallic inclusions was determined

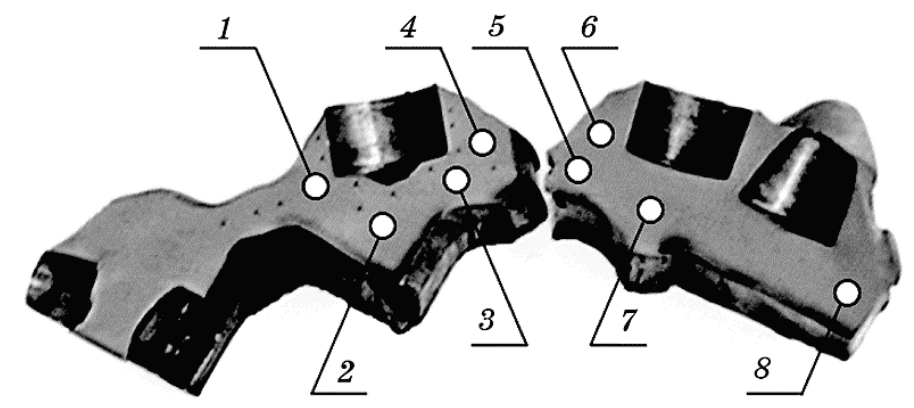

Fig. 6. General view of the template of the cone with the designation of sections of steel sampling for chemical analysis. 
according to the standard ASTM technique, method A. Non-metallic inclusions of type $B_{T} 1$ point $D_{Y T} 1$ point were detected, the rest $\left(A_{T}\right.$, $A_{Y T}, B_{Y T}, C_{T}, C_{Y T}, D_{T}$ ) were not detected. Note that, according to the requirements of ASTM E45-97, one point for non-metallic type inclusions is the limit value. It can be assumed that in some parts of the cone on such a melting of steel may be greater values of contamination.

Austenitic grain was detected by the known method of carburization according to the method, which regulates by State Standard ГOCT 5639-82. The detected grain boundaries in the form of a grid of secondary cementite were compared to the reference data of the standard tables. It was found that the grain size corresponded to 7 points for the studied cone bit, as in previous studies [5].

Assessment of the chemical composition of melting 14XH3MA-B steel from the position of the DI strength factor revealed an overestimation of DI $=4.3$. For comparison, according to ASTM A255 and SPECIFICATION 9313 Steel, the figure should be DI $=3.5 \pm 0.5$.

Macroanalysis was carried out on specially prepared cone bits templates, according to the standard methodology, which regulates State Standard ГOCT 10243-62. The test surface of the template was ground and polished and then etched with $50 \%$ hydrochloric acid at $80^{\circ} \mathrm{C}$ for $40 \mathrm{~min}$.

Macroslide analysis revealed no porosity, point inhomogeneity, or traces of segregation defects. The etching revealed barely perceptible

TABLE 1. The distribution of the chemical composition along the cross section in accordance with the scheme presented in Fig. 6.

\begin{tabular}{|c|c|c|c|c|c|c|c|c|c|c|c|}
\hline \multirow{2}{*}{ 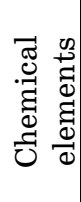 } & \multicolumn{8}{|c|}{$\begin{array}{l}\text { The chemical composition in the sections of the } \\
\text { sampling on the cone drills template, \% mass }\end{array}$} & \multirow{2}{*}{$\begin{array}{c}\text { Average, } \\
\bar{X} \\
\% \text { mass }\end{array}$} & \multirow{2}{*}{$\begin{array}{l}\text { Deviation, } \\
s, \% \text { mass }\end{array}$} & \multirow{2}{*}{\begin{tabular}{|c|} 
Steel \\
14XH3MA-B \\
according to \\
Ty14-550- \\
$51-2004$ \\
\end{tabular}} \\
\hline & No. 1 & No. 2 & 3 & No. 4 & No. 5 & 6 & No. 7 & No. 8 & & & \\
\hline $\mathrm{C}$ & 0.141 & & V & 0.1 & 0.1 & 0.1 & . & 145 & 0.142 & & 0.11 \\
\hline $\mathrm{Cr}$ & 1.47 & 1.46 & 1.47 & 1.48 & 1.50 & 1.48 & 1.46 & 1.46 & 1.473 & 0 & 1.35 \\
\hline $\mathrm{Ni}$ & 3.23 & 3.22 & 3.21 & 3.20 & 3.20 & 3.19 & 3.18 & 3.17 & 3.200 & 0.02 & $3.10-3.40$ \\
\hline Mo & 0.130 & 0.129 & 0.130 & 0.131 & 0.136 & 0.133 & 30120 & 0.130 & 0.131 & $2.39 \cdot 10^{-3}$ & $0.10-0.15$ \\
\hline $\mathrm{Mn}$ & 0.72 & 0.71 & 0.72 & 0.71 & 0.73 & 0.72 & 0.71 & 0.71 & 0.716 & $7.445 \cdot 10^{-3}$ & $0.60-0.80$ \\
\hline $\mathrm{Cu}$ & $0.19 \leftrightarrows$ & 0 . & 0.201 & 0.2 & 0.2 & 10.1 & 0.2 & .200 & 0.200 & $1.604 \cdot 10^{-3}$ & $\leq 0.25$ \\
\hline $\mathrm{Al}$ & 0.011 & 0.0 & & 0.0 & 0.6 & 0.0 & 10.0 & 0.011 & 0.011 & $5.345 \cdot 10^{-4}$ & - \\
\hline V & 0.01 & 0 & 0.018 & 0.017 & 0016 & 0.010 & 5.020 & 0 & 0.018 & $1.604 \cdot 10^{-3}$ & $\leq 0.05$ \\
\hline $\mathrm{Si}$ & 0.27 & 0.27 & 0.27 & 0.27 & 0.28 & 0.27 & 0.28 & 0.28 & 0.274 & $5.182 \cdot 10^{-3}$ & $0.20-0.35$ \\
\hline $\mathrm{S}$ & 0.005 & 00 & 00 & .00 & 0.00 & .00 & .0( & .006 & 0.0056 & $7.44 \cdot 10^{-4}$ & $\leq 0.015$ \\
\hline $\mathrm{P}$ & 0.008 & 0.008 & 0.007 & 0.007 & 0.007 & 0.008 & 0.007 & 0.007 & 0.0074 & $1.188 \cdot 10^{-3}$ & $\leq 0.015$ \\
\hline
\end{tabular}


TABLE 2. Technological and physical-mechanical parameters of the studied of melting steel 14XH3MA-B.

\begin{tabular}{|c|c|c|c|c|c|c|c|c|}
\hline \multirow{2}{*}{\multicolumn{2}{|c|}{ Parameter }} & \multicolumn{7}{|c|}{ Parameter values } \\
\hline & & \multicolumn{5}{|c|}{ Measured } & \multirow{2}{*}{\begin{tabular}{|l} 
Mean \\
45.4
\end{tabular}} & \multirow{2}{*}{\begin{tabular}{|c|}
$\begin{array}{c}\text { Regulated by } \\
\text { current } \\
\text { requirements }\end{array}$ \\
$39-45$
\end{tabular}} \\
\hline \multirow{3}{*}{$\begin{array}{l}\text { Hardening, } H R C \\
\text { on depth }\end{array}$} & $6.5 \mathrm{~mm}$ & 45 & 44.5 & 46.5 & 45 & 46 & & \\
\hline & $20 \mathrm{~mm}$ & 38.5 & 42.5 & 41 & 39 & 40 & 40.2 & $34-40$ \\
\hline & $30 \mathrm{~mm}$ & 38 & 37 & 40.5 & 39 & 41 & 39.1 & $29-39$ \\
\hline \multicolumn{2}{|c|}{ Unlimited stress $\sigma_{u}, \mathrm{MPa}$} & 1316 & 1345 & 1353 & 1328 & 1338 & 1336 & $\geq 1000$ \\
\hline \multicolumn{2}{|c|}{ Yielding stress $\sigma_{0,2}, \mathrm{MPa}$} & 1015 & 999 & 1013 & 1020 & 1010 & 1011 & $\geq 900$ \\
\hline \multicolumn{2}{|c|}{ Relative reduction $\psi, \%$} & 49 & 50 & 50 & 51 & 50 & 50 & $\geq 50$ \\
\hline \multicolumn{2}{|c|}{ Relative elongation $\delta, \%$} & 11 & 11 & 12 & 11 & 12 & 11.4 & $\geq 11$ \\
\hline \multicolumn{2}{|c|}{ Impact toughness $K C U, \mathrm{~J} / \mathrm{cm}^{2}$} & 9 & 12 & 10 & 11 & 10,5 & 10.5 & $\geq 11$ \\
\hline
\end{tabular}

fibres oriented along the axis of the cone bit, indicating that there are no perturbation in the technology of manufacturing the workpiece. Also, several cracks originating from the carburized surface of the race of the locked ball bearing and deepened into the core by $0.3-0.4 \mathrm{~mm}$ were detected. Several cracks were recorded, originating from the surface of the carburized thrust end and deepening into the core by $0.3-$ $0.6 \mathrm{~mm}$. The carburization circuit meets the requirements of the standard regulatory documents of the drill bits enterprises.

Template hardness was measured on standard equipment according to standard procedure. In Fig. 7 shows the results of the hardness

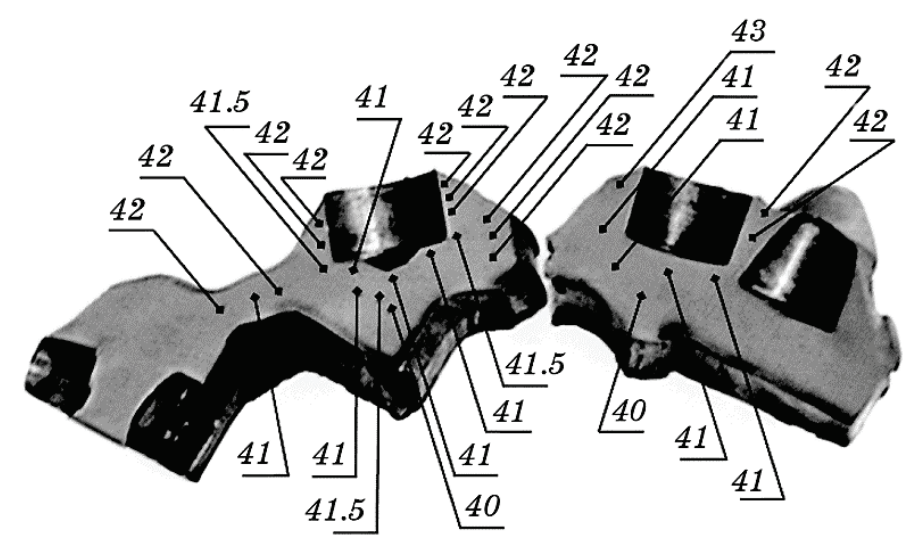

Fig. 7. The distribution of hardness values ( $H R C$ scale) is set on the template of the test cone bit. 
measurement.

It is established that the hardness of surfaces with hardened carburized layer is 61-63.5 HRC. The core in the zone of dangerous sections and in the section of the crowns with holes for the insertion of carbide teeth has slightly higher values of hardness than regulated by the current typical technical conditions for the manufacture of cones. The obtained hardness measurement data are presented in Fig. 8 and gives information about the smooth descending nature of the change in values, as well as the fact that the value of the hardness is at the upper permissible limit according to the current specifications for the manufacture of cone bits.

The microstructure of the cone bits steel was studied at specially prepared templates according to the methods and recommendations of State Standard ГОСТ 8233-56 and Management Directive РД 26-02$68 / 85$. After grinding and polishing, the investigated surfaces were etched with $4 \%$ alcohol solution of nitric acid.

The hardened carburized layer had a microstructure of $1-4 \mathrm{~b}$, residual austenite 1-4 b, carbides 1-3 b. The microstructure of the core is sorbitol perlite, or sorbitol with small inclusions of ferrite. In the microstructure of the core, ferrite-perlite strip is not detected.

Therefore, the tested melting of the steel does not provide high toughness in the core. Cracks occurring in hardened carburized layers easily extend into the core. It is known that the ratio of the area of the non-reinforced core to the total cross-sectional area of the workpiece determines the nature of the fracture. In particular, a decrease in the area of the ductile core by 0.50 causes the fragile nature of fracture in

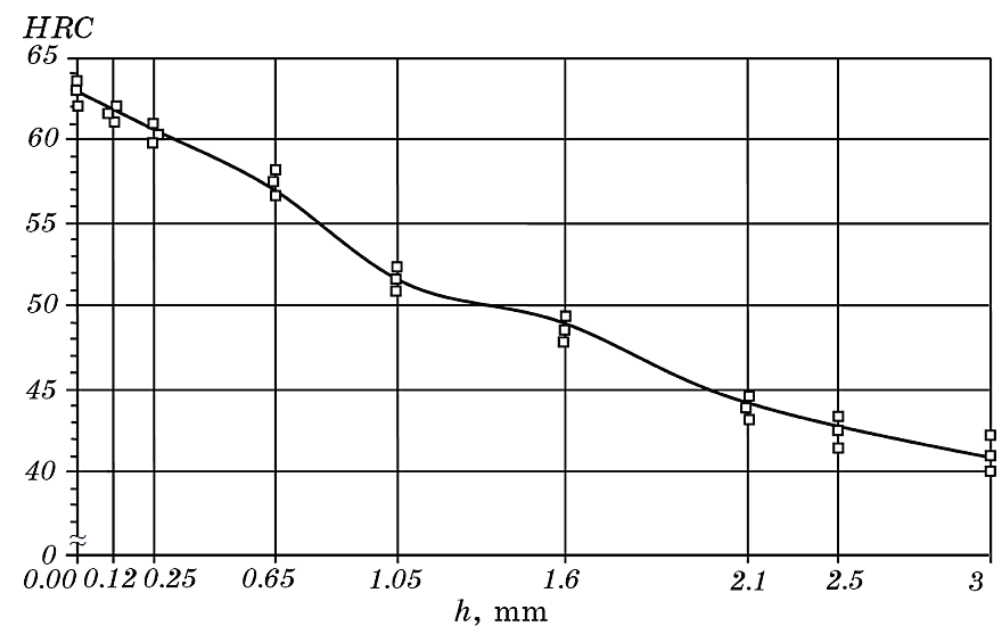

Fig. 8. The distribution of hardness in the area of hardened carburized thrust end of the test cone bit. 
a dangerous section [57]. Frequent is the sharp grows of the crack in fragile hardened surface layers and its stop in the transition area to the ductile core. In the case of destruction of specimens from 14XH3MA-B steel melts that have low plasticity, we have a sudden fragile nature.

The application to the manufacture of cone bits of electro-steels subjected to vacuum treatment does not give the effect that was obtained when applying steels of electroslag remelting. The analysis of the templates of the details of the drills revealed the fact that the values of the chemical composition, especially non-metallic inclusions, are widely scattered. In some cases, excessive values of harmful impurities were recorded. This gives grounds to claim that the vacuum treatment of steel is poor. In addition, in some cases, significant variations in the structure and chemical composition of the rolling stock delivered to the enterprise were found. This can significantly increase the release of limited soluble in the $\gamma$-phase particles or the melting of eutectics in volumes between grain boundaries, which increases the tendency for steel to form a primary rock fracture, which is justified in [57, 58]. Somewhere it is impossible to detect standard physical-mechanical and technological parameters in the input factory control. In particular, it is problematic to predict a sharp decrease in the fracture toughness of the finished cone bits due to the content of rolled chemical elements that dramatically reduce the ductility and durability of steel. It is relatively probable that this can be detected by tests of roll stock for pre-

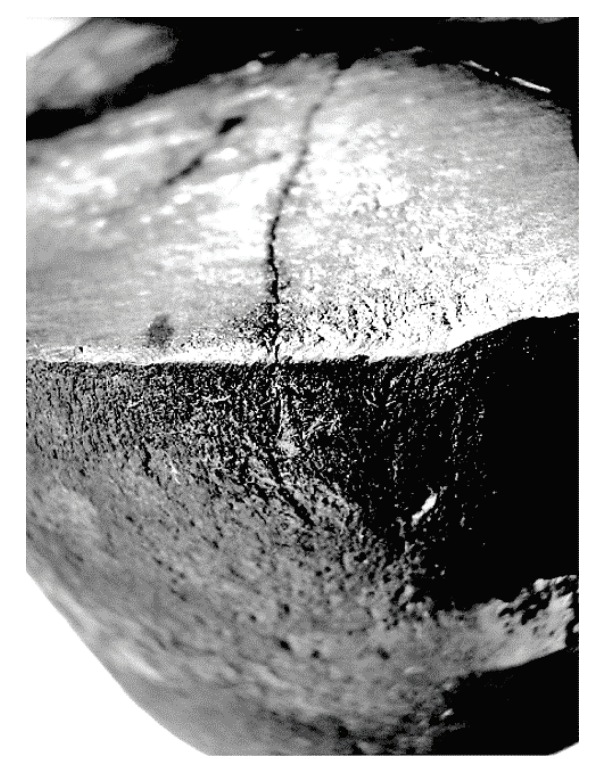

Fig. 9. Crack on the sample tested by precipitation method of rolled steel smelting 14XH3MA-B subjected to brittle fracture. 
cipitation method according to the standard procedure [3]. For example, the low values of plasticity and durability of steel melt indicate cracks formed on the tested samples (Fig. 9), which is consistent with the research [59].

It is known that the tendencies in the choice of steel smelting by leading manufacturers of drilling bits are fully justified by the requirements for high fracture toughness. In this case, the carburized and hardened layers of the imported drill bit parts exhibit high hardness and the core has high toughness and elasticity. The hardness of the subsurface layers of the carburized layer at the depth level of 0.35$0.50 \mathrm{~mm}$ should be within 57-59 HRC [3]. However, data on the nature of hardness distribution and carbon concentration under specific conditions are lacking. For this purpose, the results of chemical analysis (Table 3), metallographic studies (Fig. 10) and the physical-mechanical parameters of the bits steels of some major manufacturers of drills are presented (Table 4).

It is established that the microstructure of the hardened carburized layer is typical for all manufacturers. These are fine needle martensite 1-2 b, austenite up to $1 \mathrm{a}-2 \mathrm{a}$ b, carbides $1 \mathrm{~b}$, rarely $2 \mathrm{~b}$ (small amount of carbides). The core usually has the structure of a troostite.

Figure 11 presents a comparison of the specification requirements

TABLE 3. The chemical composition of the drill bits steel of some manufacturers.

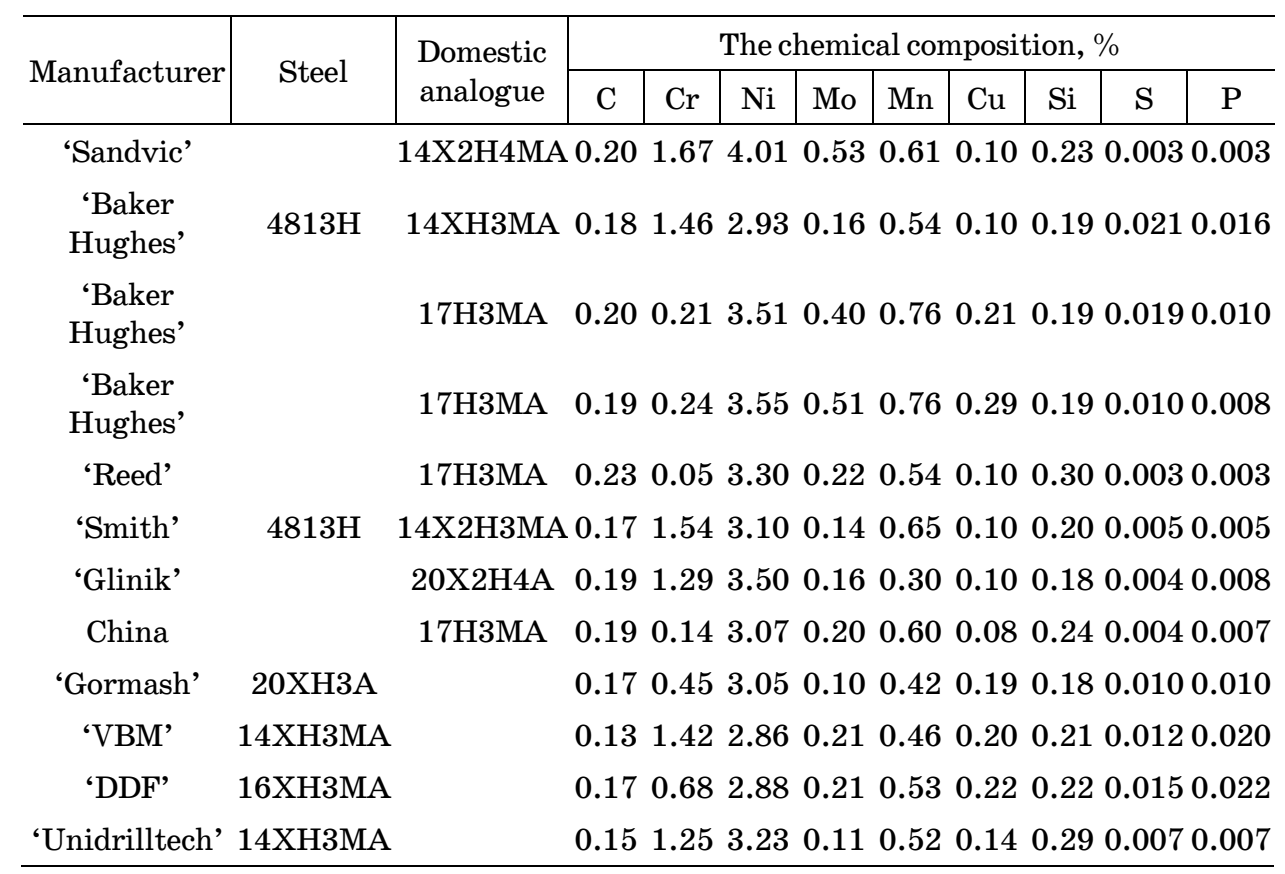




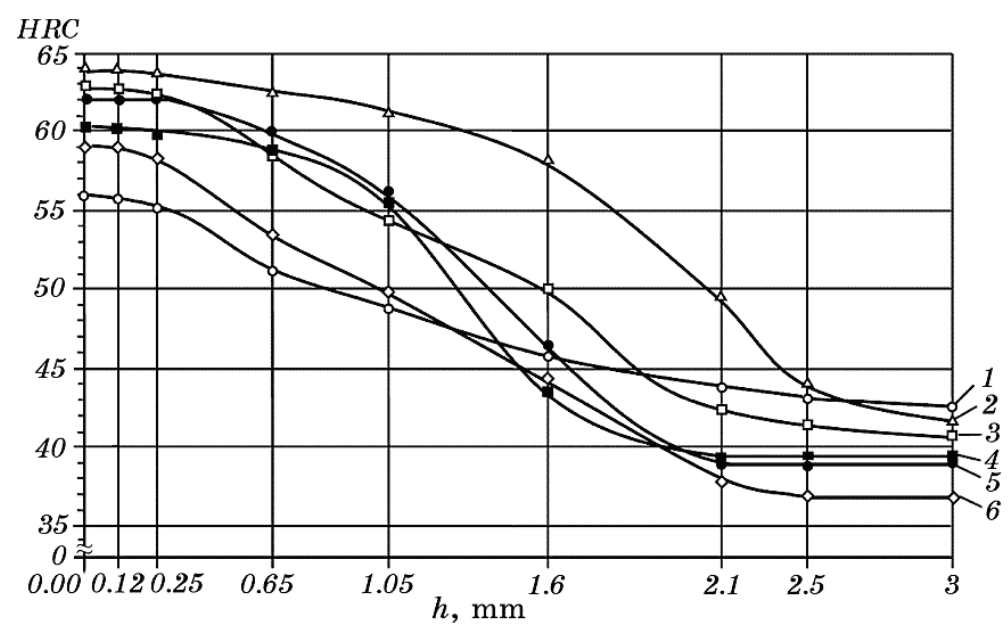

Fig. 10. Hardness distribution in the area of hardened carburized thrust end cone bit face of some drill manufacturers: 1-'Reed', 2-'Glinik', 3-'Baker Hughes', 4-'Smith', 5-'Sandvic', 6-'Gormash'.

for the quality of carburized parts of the Security Division of Dresser Industries drilling bits and the established nature of the carbon concentration distribution in the carburized Baker Hughes and Glinik cone bits layer.

The carbon distribution curve along the depth of the diffusion layer is descending, with a smooth decrease in the carbon content from the surface to the core. However, the analysis of templets made from cone bits of leading foreign manufacturers, in particular the cone bits of Baker Hughes drills revealed a somewhat different nature of the carbon distribution curve.

TABLE 4. Physico-mechanical properties of steel of some manufacturers.

\begin{tabular}{c|c|c|c|c|c|c}
\hline & $\begin{array}{c}\text { Brand of } \\
\text { steel or do- }\end{array}$ & \multicolumn{5}{|c}{ Physico-mechanical properties } \\
\cline { 3 - 7 } & $\begin{array}{c}\text { mestic ana- } \\
\text { logue }\end{array}$ & $\begin{array}{c}\sigma_{\mathrm{u}}, \\
\mathrm{MPa}\end{array}$ & $\begin{array}{c}\sigma_{0,2}, \\
\mathrm{MPa}\end{array}$ & $\begin{array}{c}\delta, \\
\%\end{array}$ & $\begin{array}{c}\psi, \\
\%\end{array}$ & $\begin{array}{c}\mathrm{KCU}, \\
\mathrm{J} / \mathrm{cm}^{2}\end{array}$ \\
\hline 'Sandvic', Sweden & 14X2H4MA & 852 & 710 & 15 & 62 & 13 \\
'Baker Hughes', USA & $4813 \mathrm{H}$ & 891 & 748 & 16 & 60 & 14 \\
'Glinik', Poland & 20X2H4A & 1070 & 840 & 13 & 66 & 12 \\
'Gormash' & 20XH3A & 1473 & 1323 & 12 & 55 & 12 \\
'VBM' & 14XH3MA & 1265 & 1115 & 12 & 50 & 12 \\
'DDF' & 16XH3MA & 890 & 810 & 14 & 60 & 25 \\
'Unidrilltech' & 14XH3MA & 1285 & 1136 & 13 & 59 & 12 \\
\hline
\end{tabular}




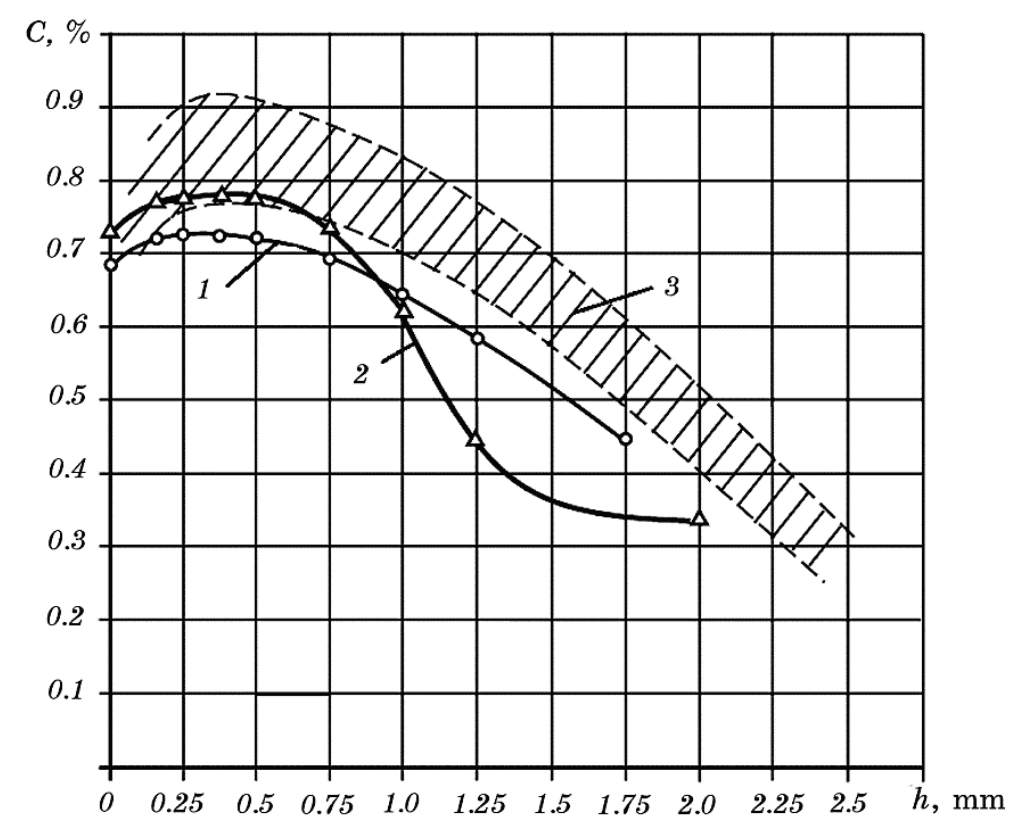

Fig. 11. Comparison of requirements for carbon content in hardened mediumsized carburized cone bits of Security Company and established values of carbon concentration in carburized layer for cone bits of Baker Hughes (1), Glin$\mathrm{ik}(2)$ and the range of recommended carbon concentrations (3).

In the area approximately corresponding to $\mathrm{j}$ the depth of the carburized layer from the surface, the area with a constant carbon concentration was detected. As the experience of hardening carburized cone bits shows this effect can be achieved by a controlled process of carburization (according to the process model) and at the stage of the second quenching. Also the specifications of 'Reed Tool Co.', 'Security DBS Dresser Industries Inc.' and others. regulate tight control of carbon concentration, noting that when carbon increases by more than $0.8 \%$ in the surface carburized layer and under conditions of suboptimal nature of distribution dramatically increases the propensity to brittle fracture of cone bits. Therefore, it is extremely important to control the heat treatment parameters, especially the second quenching and tempering. It is also important to ensure that the requirements for a rational distribution of carbon concentration and hardness of the hardened carburized layer of cones are met (Table 5).

\section{CONCLUSION}

The nature of the damage of the three-cone drill bit chisels which have 
TABLE 5. Requirements for the quality of reinforcement of cone bits of medium size drilling bits.

\begin{tabular}{|c|c|c|c|c|c|}
\hline \multirow{2}{*}{$\begin{array}{c}\text { Depth of carburized } \\
\text { layer, } \mathrm{mm}\end{array}$} & \multicolumn{2}{|c|}{$\begin{array}{c}\text { Carbon concentration } \\
C, \%\end{array}$} & \multicolumn{2}{|c|}{ Hardness, $H R C$} & \multirow[b]{2}{*}{ Microstructure } \\
\hline & $\mid \begin{array}{c}\text { Serial } \\
\text { technology }\end{array}$ & $\begin{array}{c}\text { Increased } \\
\text { require- } \\
\text { ments }\end{array}$ & $\begin{array}{c}\text { Serial } \\
\text { techno- } \\
\text { logy }\end{array}$ & \begin{tabular}{|c|}
$\begin{array}{c}\text { Increased } \\
\text { require- } \\
\text { ments }\end{array}$ \\
\end{tabular} & \\
\hline On the surface & $0.9-1.00$ & $0.80-0.90$ & $60-63$ & $60-61$ & \multirow{6}{*}{$\begin{array}{c}\text { Martensite } 1-3 \mathrm{~b} \text {, } \\
\text { austenite up to } 3 \mathrm{~b} \text {, } \\
\text { carbides } 1 \mathrm{~b} \text {, very } \\
\text { few } 3 \mathrm{~b}\end{array}$} \\
\hline At depth $0.15-0.25$ & $0.58-0,90$ & $070-0.80$ & $59-61$ & $59-60$ & \\
\hline At depth 0.40 & $0.56-0.70$ & $0.70-0.80$ & $57-59$ & $59-60$ & \\
\hline At depth 0.50 & $0.55-0.60$ & $0.60-0.80$ & $55-57$ & $56-58$ & \\
\hline At full depth & & & & & \\
\hline $1.70-1.90$ & $0.25-0.35$ & $0.40-0.45$ & $40-50$ & $45-50$ & \\
\hline Core & & & $35-45$ & $35-40$ & Sorbitoid troostite \\
\hline
\end{tabular}

lost their working capacity is described. Physical-mechanical and metallographic indices of melting of cone bits steel 14XH3MA-B which have undergone brittle destruction are established. The distribution of carbon concentration and hardness in hardened carburized layers of cone bits was established. It was found that the melting of 14XH3MA$\mathrm{B}$ steel has low plasticity and is prone to brittle fracture. The hardened carburized layer has a martensite structure which is characterized by a chaotic distribution of carbides of various sizes. Therefore, it is important to properly select the parameters of the heat treatment of the cone bits. This is justified by the data of metallographic analysis of the established indices of the most common steels used in the world practice of making drills. The chemical composition and physicalmechanical and technological indices of the foreign drill bits steels were established. The requirements for the choice of the chemical composition of steel, which are usually CrNiMo steel, are consequently fine-grained with regulated hardening were suggested. Particular attention should be paid to the content of $\mathrm{Mn}$, which is $0.54-0.76 \%$, as well as the content of alloying chemical elements, which should provide an optimal amount of homogeneous small carbides in the carburized layer, without their excess in the form of segregation or separate above $3 \mathrm{~b}$ by standard scale. To prevent premature loss of working capacity of cone bits, requirements on the quality of technology of hardening of cone bits of domestic production (distribution of concentration of carbon and hardness in hardened carburized layers and core) are formulated.

In the future, it is promising to study the possibility of obtaining an effective character of the distribution of carbon concentration and 
hardness and to develop rational parameters of heat treatment of cone cutters of rock drill bits.

\section{REFERENCES}

1. Burovoy Porodorazrushayushchiy Instrument. Tom 1. Sharoshechnye Dolota. Mezhdunarodnyy Translyator-Spravochnik [Drilling Rock Cutting Tool: International Engineering Encyclopedia (International Translator-Guide)], vol. 1: Drill Bits] (Ed. V. Ya. Kershenbaum, A. V. Torgashov, and A. G. Messer) (Moscow: Oil and Gas: 2003) (in Russian).

2. R. S. Yakym, Yu. D. Petryna, T. B. Pasynovich, and A. Yu. Kolodiy, Mechanical Science. Nos. 1-2: 26 (2010) (in Ukrainian).

3. R. S. Yakym and Yu. D. Petryna, Teoriya i Praktika Zabezpechennya Yakosti ta Ekspluatatsiynykh Pokaznykiv Tsementovanykh Detaley Sharoshkovkykh Burovykh Dolit: Monografiya [Theory and Practice of Quality Assurance and Performance of Carburized Parts of Drill Bits: Monograph] (Ivano-Frankivsk: IFNTUNG Publishing House: 2011) (in Ukrainian).

4. R. S. Yakym and D. Yu. Petryna, J. Hydrocarbon Power Eng., 4, Iss. 2: 49 (2017).

5. R. S. Yakym and D. Yu. Petryna, Naftogazova Energetyka, No. 1 (31): 72 (2019).

6. L. S. Saakiyan, A. P. Efremov, and L. Ya. Ropyak, Protection of Metals, 25 (2): 185 (1989).

7. L. S. Saakiyan, A. P. Efremov, L. Ya. Ropyak, and A. V. Gorbatskii, Soviet Mater. Sci., 23 (3): 267 (1987).

8. D. Yu. Petryna, V. M. Hohol', Yu. D. Petryna, O. I. Zvirko, and Y. M. Nykyforchyn, Mater. Sci., 51, (5): 666 (2016).

9. O. T. Tsyrulnyk, H. M. Nykyforchyn, O. I. Zvirko, and D. Yu. Petryna, Fiziko-Khimicheskaya Mekhanika Materialov, 40 (2): 125 (2004) (in Ukrainian).

10. O. I. Zvirko, Mater. Sci., 52 (4): 588 (2017).

11. Y. Striletskyi, V. Rovinskyi, and O. Yevchuk, Eastern-European J. Enterprise Technol., 3 (9): 24 (2016).

12. Yu. Yo. Striletskyy and V. A. Rovinskyy, Metallofiz. Noveishie Tekhnol., 39, No. 10: 1377 (2017).

13. V. B. Kopei, O. R. Onysko, and V. G. Panchuk, IOP Conference Series: Mater. Sci.Eng., 477 (1): 012032 (2019).

14. T. Pryhorovska and L. Ropyak, 2019 IEEE 8th International Conference on Advanced Optoelectronics and Lasers (CAOL) (Bulgaria: Sozopol: 2019), p. 493.

15. O. Vlasiy, V. Mazurenko, L. Ropyak, and O. Rogal, Eastern-European J. Enterprise Technol., 1 (7-85): 25 (2017).

16. I. Shatskyi, L. Ropyak, and A. Velychkovych, Engineering Solid Mechanics, 8 (4): 301 (2020).

17. X. Zhu, and Z. Zhang, Natural Gas Industry B, 4, Iss. 5: 374 (2017).

18. V. Aulin, S. Lysenko, O. Lyashuk, A. Hrinkiv, D. Velykodnyi, Y. Vovk, D. Holub, and A. Chernai, Tribology in Industry, 41 (2): 156 (2019).

19. H. Zhang, D. D. Jayaseelan, I. Bogomol, M. J. Reece, C. Hu, S. Grasso, and 
W. E. Lee, J.Alloys Compd., 785: 958 (2019).

20. A. G. Kolmakov, V. I. Antipov, S. A. Klimenko, A. S. Manokhin, M. Yu. Kopeikina, V. N. Tkach, M. L. Kheifets, and L. Tanovich, J. Superhard Materials, 35 (6): 399 (2013).

21. L. Ropyak, I. Schuliar, and O. Bohachenko, Eastern-European J. Enterprise Technol., 1, No. 5: 53 (2016).

22. V. Kopei, O. Onysko, and V. Panchuk, Lecture Notes in Mechanical Engineering, 149 (2020).

23. A. Manokhin, S. Klymenko, V. Beresnev, V. Zakiev, and S. Klymenko, Lecture Notes in Mechanical Engineering, 206 (2020).

24. S. A. Klimenko, I. A. Podchernjaeva, V. M. Beresnev, V. M. Panashenko, S. An. Klimenko, and M. Yu. Kopeikina, J. Superhard Mater., 36 (3): 208 (2014).

25. V. I. Lavrinenko, G. D. Il'Nitskaya, G. A. Petasyuk, V. N. Tkach, V. V. Smokvina, V. S. Shamraeva, I. N. Zaitseva, and D. G. Muzychka, J. Superhard Mater., 35 (5): 309 (2013).

26. O. Karpov, P. Nosko, P. Fil, O. Nosko, and U. Olofsson, Mechanism and Machine Theory, 114: 1 (2017).

27. U. Heisel, S. Pasternak, M. Storchak, M. Schaal, and S. Y. Danilchenko, $Z W F$ Zeitschrift fur Wirtschaftlichen Fabrikbetrieb, 105, Nos. 7-8: 649 (2010).

28. A. Krivosheya, J. Danilchenko, M. Storchak, and S. Pasternak, Mechanisms and Machine Science, 34: 425 (2016).

29. V. Pasichnyk and O. Khmurenko, Eastern-European J.Enterprise Technol., 4, No. $7: 15$ (2015).

30. V. B. Tarelnyk, O. P. Gaponova, I. V. Konoplianchenko, N. S. Evtushenko, and V. A. Herasymenko, Metallofiz. Noveishie Tekhnol., 40, No. 2: 235 (2018).

31. V. B. Tarelnyk, O. P. Gaponova, Ye. V. Konoplyanchenko, N. S. Yevtushenko, and V. O. Herasymenko, Metallofiz. Noveishie Tekhnol., 40, No. 6: 795 (2018).

32. S. I. Kryshtopa, D. Yu. Petryna, I. M. Bogatchuk, I. B. Prun'ko, and V. M. Mel'nyk, Alloying Mater. Sci., 53 (3): 351 (2017).

33 I. P. Shatskyi, V. V. Perepichka, and L. Ya. Ropyak, Metallofiz. Noveishie Tekhnol., 42, No. 1: 69 (2020).

34. L. Y. Ropyak, I. P. Shatskyi, and M. V. Makoviichuk, Metallofiz. Noveishie Tekhnol., 41, No. 5: 647 (2019).

35 L. Ropyak and V. Ostapovych, Eastern-European J.Enterprise Technol., 2 (5): 50 (2016).

36. V. A. Tatarenko, T. M. Radchenko, and V. M. Nadutov, Metallofiz. Noveishie Tekhnol., 25, No. 10: 1303 (2003).

37. V. M. Nadutov, Ye. O. Svystunov, S. G. Kosintsev, and V. A. Tatarenko, Hyperfine Interactions, 168, Nos. 1-3: 929 (2006).

38. T. Pryhorovska, Engineering Solid Mechanics, 6 (4): 315 (2018).

39. T. A. Pryhorovska and S. S. Chaplinskiy, Oil Industry, 1: 38 (2018).

40. N. Volchenko, A. Volchenko, D. Volchenko, P. Poliakov, V. Malyk, D. Zhuravliov, V. Vytvytskyi, and P. Krasin, Eastern-European J. Enterprise Technol., 1, No. 5 (97): 47 (2019).

41. T. O. Pryhorovska, 52nd U.S. Rock Mechanics/Geomechanics Symposium (June 17-20, 2018, Seattle) (Code 138804).

42. L. Belkacem, N. Abdelbaki, M. Gaceb, E. Bouali, and M. Bettayeb, Chemical Engineering Transactions, 61: 1099 (2017). 
43. E. I. Kryzhanivs'kyi, R. S. Yakym, L. E. Shmandrovs'kyi, and Yu. D. Petryna, Mater.Sci., 46, Iss. 5: 607 (2011).

44. M. Dutkiewicz, I. Gołębiowska, I. Shatskyi, V. Shopa, and A. Velychkovych, MATEC Web of Conferences, 178: 06010 (2018).

45. A. Velychkovych, I. Petryk, and L. Ropyak, Shock and Vibration, Art. No. 3292713 (2020).

46. A. S. Velichkovich, Chemical and Petroleum Engineering, 43, Nos. 7-8: 458 (2007).

47. I. Shatskyi, I. Popadyuk, and A. Velychkovych, Springer Proceedings in Mathematics \& Statistics. Springer, Cham., 249: 343 (2018).

48. A. Velichkovich, T. Dalyak, and I. Petryk, Rev. IFP Energies Nouvelles, 73, Iss. 34: 1 (2018).

49. D. A. Panevnik, and A. S. Velichkovich, Oil Industry, 1: 70 (2017).

50. O. Vytyaz, I. Chudyk, and V. Mykhailiuk, New Developments in Mining Engineering 2015: Theoretical and Practical Solutions of Mineral Resources Mining, 591 (2015).

51. I. P. Shats'kyi, O. M. Lyskanych, and V. A. Kornuta, Strength Mater., 48: 469 (2016).

52. K. G. Levchuk, Metallofiz. Noveishie Tekhnol., 40, No. 5: 701 (2018).

53. K. G. Levchuk, SOCAR Proceedings Oil Gas Scientific Research Project Institute, 23 (2017).

54. K. G. Levchuk, V. M. Moisyshyn, and I. V. Tsidylo, Metallofiz. Noveishie Tekhnol., 38, No. 12: 1655 (2016) (in Ukrainian).

55. V. N. Vinogradov, G. M. Sorokin, and V. A. Dotsenko, Abrazivnoe Iznashivanie Burilnogo Instrumenta [Abrasive Wear of a Rock Cutting Tools] (Moscow: Nedra: 1980) (in Russian).

56. R. A. Cutler, E. C. Goodman, R. R. Hendricks, and W. C. Leslie, Elevated Temperature Toughness and Fatigue Testing of Steels for Geothermal Applications (Final Report: BNL Contract No. 492267-S, Number of Registration: October, 1981, TR 81-97) [Submitted to Brookhaven National Laboratory, Attn: Dr. Daniel Van Rooyen] (New York: Terratek: 1981).

57. Yu. D. Petryna, Rozrobka Naukovo-Prykladnykh Osnov Pidvyshchennya Dovhovichnosti Burovykh Dolit Shlyakhom Ratsionalnoho Vykorystannya Materialiv [Development of Scientifically Applied Bases of Increase of Durability of Drill Bits by Rational Use of Materials] (Thesis of Disser. for Dr. Tech. Sci.) (Ivano-Frankivsk: Ivano-Frankivsk State Technical University of Oil and Gas: 1996) (in Ukrainian).

58. G. M. Sorokin and I. B. Kurakin, Sistemnyy Analiz i Kompleksnye Kriterii Prochnosti Staley (Moscow: Nedra: 2011).

59. Ya. E. Goldstein, and T. L. Mushtakova, Metalloved. Termicheskaya Obrabotka Metallov, No. 5: 70 (1978) (in Russian). 